\title{
The Role and Importance of Social Awareness in Energy Management in Highly Developed Countries
}

\author{
Grzegorz Maśloch
}

\begin{abstract}
Energy as a strategic sector of the economy of any country has a significant impact on its socio-economic determinants of development. It is also a sector of the economy with a negative impact on the natural environment and, hence, on human health. Thus, it directly affects the level and quality of life of citizens. The aim of the article is therefore to present possible social attitudes towards energy management problems in highly developed countries.
\end{abstract}

Index Terms-Energy, social attitudes, developed countries.

\section{INTRODUCTION}

There is a growing number of unfavorable phenomena in the global economy, forcing a new approach towards energy policy, natural resources and the environment. Constant growth in energy prices, growing demand for energy, failures of energy systems, increasing environmental pollution and political tensions require a new approach towards the broadly defined energy policy. The social awareness and attitudes of residents towards the process of energy production, processing and consumption is also gaining a new meaning.

The aim of the article is therefore to present possible social attitudes towards energy management problems in highly developed countries.

\section{II.PROBLEMS OF DEVELOPMENT OF MODERN ENERGY SECTOR}

Energy sector and the energy it generates are essential for the functioning of societies and economies, and the ways of its use affect all aspects of socio-economic life, as well as political and environmental issues. Energy is also the basis for the economic and social development of modern states. It is the driving force of technological and economic development and has a significant impact on the level and quality of life. However, through the use of fossil fuels, which consumption for energy purposes is and will remain the main source of energy for many years, energy sector is one of the biggest dilemmas in the world from the point of view of its impact on the natural environment. As energy is necessary to ensure the internal and external security of the region / state, energy sector issues are fundamental challenges which have a direct impact on the functioning and development of societies and economies.

Economic development and the increase in the society's welfare are therefore possible owing to efficiently and effectively functioning energy sector. Energy sector is commonly recognized as a "key sector" having a significant impact on both the development and competitiveness of other sectors of the economy, as well as on the quality of life of the society. There is a common belief that energy sector is strongly centralized and characterized by features specific to the natural monopoly and that its services and products are characterized by the specific nature of public goods. It also has a key impact on the degree and type of infrastructure of a given region or country.

Currently, economies around the world are, and for decade will continue to depend heavily on energy based on fossil fuels. As estimates show, the potential of fossil fuels is still significant. The largest reserves of fossil fuels in the world are coal, which at the current level of consumption is sufficient for about 100 years. Substantially smaller reserves are in the case of oil and gas, which are sufficient for about 50 years [1]. With regard to the current consumption, there are still huge reserves of fossil fuels that guarantee the possibility of global economic development in the next decades. It is also important to bear in mind that new discoveries and technical progress in the mining or processing of fossil fuels can still significantly improve these possibilities [2]. However, most of the recognized and available fossil fuels remain under the control of underdeveloped countries. For example, the European Union has little resources, which directly makes it dependent on the import of fossil fuels.

As the possible resource service life is shortened, the price of fuel obtained from it tends to increase. Therefore, the demand for fuel obtained from a given raw material decreases and is replaced by other, alternative fuel types. This process tends to create conditions in which a given fossil fuel can be used for a longer period than it is indicated in current research. In the perspective of the next decades, fossil fuels will continue to be intensively exploited. As shown by numerous studies, non-renewable energy resources in the world, according to the Hubbert curve, are located on the peak of the global curve or have even crossed it, which indicates that they have already been consumed in half or even more. Therefore, it should be clearly concluded that fossil fuel reserves are limited and current models of energy consumption and growth are not sustainable in the long run. [3]. In addition, the use of energy from conventional sources is inconsistent with the objectives of sustainable development, which consequently results in, inter alia: negative impact on the natural environment (especially atmospheric air), 
- the negative impact of harmful emissions arising from the operation of conventional energy sector on human health,

- limited development possibilities of a significant part of the world population that has no access to energy services,

- the lack of social stability, which is caused by growing inequalities in access to energy,

- issues related to ensuring energy security in the case of countries / regions that significantly use energy from imports,

- the loss of the possibility of full use of raw materials in the future (action against the principles of the economy striving for a closed circuit).

Also in the case of nuclear energy numerous problems can be encountered. Despite the fact that the advantages of nuclear energy are usually not questioned, as shown by extensive scientific research, in many countries the society treats the nuclear power plants operating in their regions with disgust and fear, and the majority are strongly opposed to new projects. The main concerns are the risk of failure and terrorist threat [4]. The economic costs associated with the revitalization of the area after closing nuclear power plants are also significant [5]. This leads to a situation in which a large part of the world considers nuclear energy to be very dangerous and makes the decision to close further power plants. Confirmation of this thesis are scenarios for the development of nuclear energy developed by organizations supporting its development (e.g. the International Atomic Energy Agency), which even in the most favourable variants do not envisage increasing its role in the global energy balance [6].

The demand for energy is an important, authentic indicator showing the development of humanity in a given region in its basic aspects (longevity, skills, innovation, standard of living, etc.) [7]. Thus, socio-economic development is closely related to the increase in energy consumption, which is due to, inter alia, growing population in the world, increase in living standards and technological progress. As a consequence, this results in an increase in the demand for limited energy resources and natural resources, transfer of resources to highly developed countries and deepening disproportions in development between rich and poor countries and progressive losses of biodiversity.

The analysis of energy consumption forecasts in the world [8] clearly indicates that in the coming decades a steady, dynamic growth in energy demand should be expected. According to the forecasts presented in Table I, global energy consumption in the coming decades will systematically grow.

TABLE I: ENERGY CONSUMPTION FORECAST FOR THE WORLD [IN EJ]

\begin{tabular}{lcc}
\hline \multicolumn{1}{c}{ forecast } & 2020 & 2030 \\
\hline 1. BP & 600.72 & 686.62 \\
2. EIA & 663.49 & 757.17 \\
3. EC & 600.72 & 696.98 \\
4. Shell & $628-650$ & $692-734$ \\
\hline \hline
\end{tabular}

Sources: Own study based on: 1. BP Energy Outlook - 2017 edition, Available:

http://www.bp.com/en/global/corporate/energy-economics/energy-outlook/ energy-outlook-downloads.html, 2. International Energy Outlook Reference Case tables released: May 11, 2016, U.S. Energy Information Administration (EIA), p. 25; 3. World Energy Technology Outlook - 2050, WETO H2, p. 120; 4. Shell Energy Scenarios to 2050, Shell International BV, pp. 17-46.

Forecasts for global consumption according to individual sources clearly indicate an increasing demand for energy, which in the perspective of 2040 will be produced mainly from fossil fuels. In the case of nuclear energy, production will be maintained at the current level. On the global scale, the most dynamic development will be in renewable energy which will play an increasingly important role in securing the world's energy needs (Fig. 1).

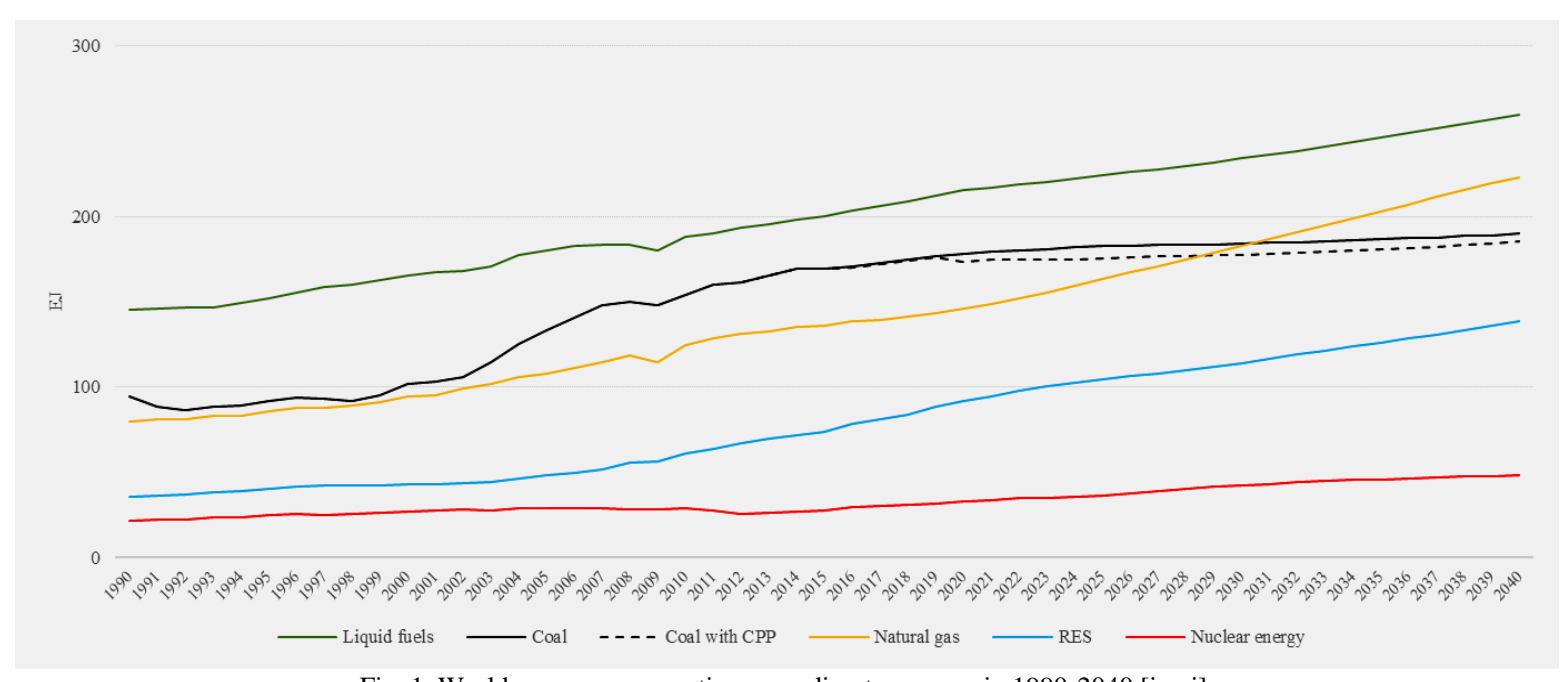

Fig. 1. World energy consumption according to sources in 1990-2040 [in ej]. Sources: Own study based on: https://www.eia.gov/outlooks/ieo/world.cfm

As the demand for energy increases due to the growth in population and economy [9], savings in energy consumption can only be achieved by increasing energy efficiency. However, a problem arises here, defined in the subject literature as a "rebound effect" or a "Jevons paradox" [10]. According to this concept, the introduction of new technologies or organizational solutions aimed at increasing energy efficiency brings some side effects manifested by 
increased consumption.

Considerations on the energy sector cannot be made without considering its impact on the environment. The theoretical approach depicting the impact of human activities caused, among others, by the use of energy resources for the natural environment is reflected in the environmental curve of Kuznets (Fig. 2), according to which there is a relationship between the welfare and the devastation and the use of natural resources. According to the theory proposed by Kuznets, in every economy and society there is a saturation point, above which an increasing importance is attached to the condition and quality of the natural environment. Therefore, it can be concluded that highly developed countries that will have achieved a high level of economic development and guaranteed their inhabitants a high quality of life will pay more and more attention to issues related to pro-ecological technologies and behaviors. This is determined by both economic policy and the pressure of the society that is increasingly appreciating the issues of high quality of life which is guaranteed by the access to safe and clean energy as well as an unspoilt and uncontaminated natural environment.

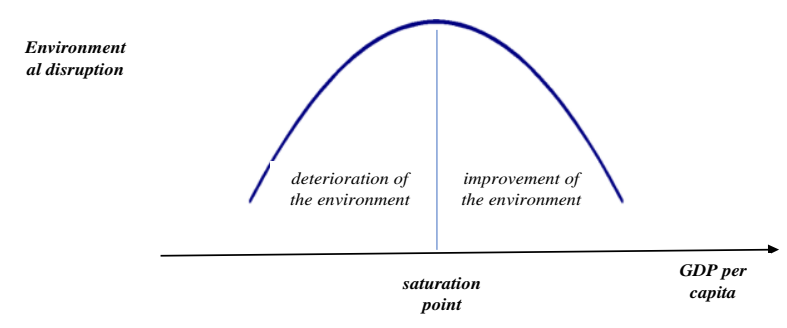

Fig. 2. Environmental Kuznets curve.

In the early stages of economic development, environmental pollution and the consumption of natural resources strongly increases, but after reaching a certain level of income per person (saturation point), which may vary depending on many factors [11], the trend reverses. Thus, with high incomes per capita, economic growth leads to an improvement in the environment and a reduction in the consumption of natural resources [12]. Thus, the environmental curve of Kuznets indicates that underdeveloped countries are more likely to accept greater pressure on the environment compared to highly developed countries, which are more likely to take initiatives to reduce pollution [13].

Due to different needs, an approach to global problems in the area of energy production and consumption, and an obvious conflict of interest, there is a risk of international tensions. As the analysis of historical statistical data on energy use and efficiency shows, along with the ongoing socio-economic development the majority of highly developed countries in the world increased and still increases the demand for energy. As a consequence, along with the increase in the quality of life in highly developed countries, there is a need to incur increasing environmental costs of energy consumption. This has led to a situation in which there is a serious ethical problem whether highly developed countries have the right to impose strict norms and standards with regard to obtaining and use of energy and whether as a result they have the right to prohibit developing countries from obtaining the necessary amount of energy with the same obtaining techniques which they have recently used themselves.

However, underdeveloped countries face dilemmas whether to follow the path that highly developed countries have taken with all of these ecological consequences, or on the contrary, make a developmental jump and immediately apply clean, environmentally friendly technologies [14]. Obviously, this is a debatable issue, and the energy revolution to be made without the development of conventional energy requires breaking down the barrier of knowledge. However, according to the analysis of telecommunications transformation in Africa, where practically in many regions the stage of development of fixed telephony has been omitted, such revolutions are possible and effective.

Highly developed countries implement a policy aimed at reducing the consumption of fossil fuels, which is obtained by introducing various solutions. Therefore, they undertake activities aimed at increasing the share of energy production from renewable sources or to increase energy efficiency and energy-saving technologies. The implementation of stricter standards and rules for the production and consumption of energy and its impact on the natural environment leads to the "escape of emissions beyond the boundaries" [15]. The consequence of such practices may be the transfer of the most emission-intensive and energy-intensive production to poorly developed countries with lower standards in terms of working conditions or the natural environment [16].

The problem that still remains to be solved is the fact that market prices of energy in most countries (even highly developed) do not take into account in any way the external effects and adverse effects of the use of fossil fuels. This therefore leads to an obvious situation in which the market price of energy obtained from fossil fuels is significantly lower than the energy generated from the available alternative energy sources. At the same time, it should be clearly stated that the implementation of measures aimed at improving environmental standards in the energy sector means the need to incur huge economic costs. It will also be necessary to make a choice in the social sphere between material wealth and the richness of the natural environment. The basic possible directions of impact on the improvement of the natural environment in terms of energy production and consumption are [17]: conscious sacrifice, clean fuels, reduction of emissions, the improvement of energy efficiency and the change of fuel.

The practical implementation of the above directions of impact on energy production and consumption can be carried out in a single-track manner or - as often is the case - a mix of these elements. The implementation of each option entails specific, very often significant costs. However, these costs must be incurred in order to implement energy mixes in economies that will enable societies to develop securely and sustainably. The key issue in this respect is undoubtedly the level of technological advancement and available technologies. However, political or social factors that determine the degree of acceptance of innovative and pro-ecological solutions can not be forgotten. 


\section{The Role OF ENERGY SeCTOR IN THE SOCIO-ECONOMIC DEVELOPMENT AND ITS IMPACT ON THE NATURAL ENVIRONMENT}

Development can be considered in economic, social and environmental terms. Societies, developing the economy, strive to improve the quality of life, which requires securing specific energy needs. Energy is produced and used in a specific natural environment. Nowadays, the challenge is to build such relationships between society, the economy and the natural environment in which sustainable development will be possible.

In the subject literature there is a common view that the principle of sustainable development cannot be implemented without introducing a sustainable energy economy. Undoubtedly, economic development and environmental problems cannot be considered separately, but must be analyzed as processes with a high degree of interdependence. It means, therefore, that the implementation of the sustainable development goals will be possible in the green economy, where sustainable energy share will be an integral part of its success.

Sustainable energy is a way of generating and managing energy, which ensures sustainable access to its sufficient quantity for present and future generations, at the same time limiting the negative impacts of its production and management for the natural environment (including climate change). In order to implement the concept of sustainable energy, it is important to increase the share of renewable energy in such a way that it gradually reduces the use of traditional energy resources. Regardless of some discrepancies in defining sustainable development and the role of energy in it [18], virtually all current energy systems in the world do not meet definitional goals. This is determined by the fact that the power industry is responsible for over $80 \%$ of greenhouse gas emissions emitted by human activities [19]. It is obvious that the choice of energy sources depends on geographical conditions, economic situation, availability of resources and security of supply. Environmental concerns related to gas emissions and global warming force us to gradually abandon the use of non-renewable resources for energy purposes. Therefore, the prices of energy resources depend not only on their availability or calorific value, but also on the impact on the natural environment [20].

The basic principle of sustainable energy sector is the effective use of available energy, human, economic and natural resources. The implementation of this principle takes place in a socio-economic and political environment in which certain patterns of consumption, behavior and preferences have been shaped. The effects of implementation of the sustainable energy principles are issues related to the natural environment (e.g. reduction of pollution, improvement of the quality of atmospheric air) and the organization and functioning of society and the economy (e.g. access and use of energy, cultural and political determinants [21].

An important change in the implementation of sustainable energy principles brings an increasing importance (especially in highly developed countries) attached to problems related to the quality of life [22]. The quality of life is understood as the degree of satisfying all society's needs (both material and non-material). Expectations reported by the public concern the increasingly broad range of services or respecting values. Therefore, public authorities, companies or individual citizens are required to provide higher and higher quality products and standards of services and respect for values, including pro-ecological and pro-environmental attitudes.

An important consequence of the implementation of sustainable energy principles is the recognition that sustainable economic growth and progressive globalization are not the best ways to achieve a higher standard of living and social well-being if as a consequence it leads to inequalities, hidden costs and greater sensitivity of local economies to global restructuring and economic shocks caused by external factors. Thus, the new economy favors the development of decentralized social and economic organizations and territorial self-government, proposing an evolution from the contemporary international economy to an elite, decentralized and multilevel global economic system [23]. Sustainable energy is therefore characterized by the use of energy sources that:

- are widely available,

- will not significantly deplete non-renewable resources,

- do not emit pollutants or other substances hazardous to people and the environment,

- are not related to the acceptance and reinforcement of threats to people and the environment.

Various, very often different approaches to energy problems in individual countries or regions of the world lead, in consequence, to situations in which opposing interests often clash. On the one hand, it is common knowledge that energy obtained from fossil fuels will dominate for several decades. This is determined by the relative prices of fossil fuels, which by not including all external costs or lost opportunities, will still be relatively inexpensive in the coming years. Additionally, it is important to be aware that conventional energy is supported by the extensive infrastructure of mines, pipelines, power plants, railway lines, gas stations, tankers, vehicles, etc. Guarantors to maintain the current status quo are also fuel and energy corporations, whose one of the goals is to inhibit initiatives (technical, technological, financial or organizational) that could jeopardize their market position. In addition, any changes in conventional energy have a significant impact on public mood, especially in regions where mining functions predominate or services for conventional energy are produced. As a consequence, very strong political and economic centers that provide protection and continuity of investments in conventional energy operate around the world [24]. On the other hand, the ability to maintain energy consumption and secure the growth of energy demand using non-renewable resources is not sustainable in the long term. Renewable energy sources will be common when they become more competitive in relation to energy obtained from fossil fuels. Greater relative competitiveness should be understood mainly as the ratio of relative prices. It is therefore obvious that instead of idle and unreflective waiting for the increase in prices of energy obtained from fossil fuels, 
countries or regions can support the development of energy from renewable sources.

Similarly, J. Rifkin speaks about the changes taking place in the energy sector writing about the third industrial revolution and the upcoming "post-carbon era" and its five pillars, to which he included [25]:

- development of renewable energy,

- equipping buildings with microinstallations, allowing the consumption of renewable energy produced in a given building,

- the use of energy storage technologies on every farm,

- the use of network management and the sale of surplus energy,

- transport based on innovative power supply (e.g. helium fuel and electricity).

The key aspects of research in modern economies regarding the energy sector are activities related to:

- clean coal technologies,

- smart grids,

- energy storage,

- new technologies of renewable energy sources,

- power industry striving to eliminate "low emissions",

- prosumer energy,

- E-mobility,

- new business models (organizational, legal and financial).

\section{THE IMPACT OF PUBliC AWARENESS ON THE POSSIBILITIES AND DIRECTIONS OF ENERGY MANAGEMENT}

Social awareness is commonly defined as a "set of beliefs and views characteristic of a given community" [26]. Social awareness can therefore be determined by reference to the following criteria [27]:

- jointly shared beliefs existing among members of the community,

- making members of the community aware of belonging to the community,

- making appropriate, individual or collective actions based on these beliefs.

Processes related to socio-economic development occurring in the modern world lead to the development of social awareness, which not only transforms along with the introduced systemic changes, but is also an important factor affecting the ongoing transformation. In practical terms, this means that social awareness plays a modifying role, which may prove to be either a beneficial or inhibiting factor, or even a factor preventing change from occurring [28]. Changes in social awareness and, consequently, in social attitudes are influenced by systemic changes that change the current practices or behaviors. They are particularly problematic in the situations where they are introduced in a violent and revolutionary manner.

Social attitudes play an important role in the process of the development of energy sector. Due to the innovative nature of modern energy sector, the possibility of carrying out violent changes that transform energy in many cases, for obvious reasons, meets with various fears and social expectations.

The social aspects related to energy sector can be grouped into five categories:

1. The spatial organization of the energy system (referring to the spatial location of the energy sector (including mainly the renewable one, characterized by a dispersed character and aimed at ensuring a balanced level of consumption in a given area.) It regards the acceptance of individual installations and their interference in the space.

2. Governance structures (concerns the institutional, political and administrative organization of the energy sector). The key issue in this category is the problem of legal, administrative or proprietary power over energy and the possibility of cooperation between renewable energy and conventional energy.

3. Political economy (a category that deals with the issue of distribution of benefits and costs arising from the use of energy). In its scope, issues related to individual and group investment decisions, building new economic initiatives or the impact of energy on the labor market are considered.

4. Ecological strategy (concerns the change of the way the communities affect the natural environment through the use of renewable energy sources or other pro-ecological solutions). In this category, relations between society and the natural environment are considered, as well as the contribution of energy to the ability to counteract climate change and to ensure ecological safety.

5. Widely understood energy security (concerns the impact of energy on the quality and the standard of living through the possibilities of providing safe energy for society and their needs). The important issue is also the impact of innovative energy solutions on the possibility of achieving energy self-sufficiency and the independence of the economy and society from the export of energy resources or energy.

In world sociological literature, the attention is drawn to the fact that energy rarely reaches the consciousness of societies or politicians [29]. Every entity or person uses energy for their activities which affects the natural environment. However, the awareness of these processes in society and among entrepreneurs is low. Among the societies, there is still a low awareness of the benefits that the economy and society would gain basing their production on, for example, the energy from renewable sources. According to studies on social acceptance of individual energy sources or preferences regarding specific types of installations, renewable energy sources are definitely perceived as positive, and coal is perceived as much worse (nuclear fuel is also assessed poorly) [30].

When analyzing investment projects in renewable energy, as well as for the entire energy sector, NIMBY effects should be identified and recognized. As shown in the subject literature and case studies, NIMBY effects in renewable energy have a much milder character than, say, nuclear or conventional energy. In the case of renewable energy sector, the vast majority refer to a wind farm or construction of a waste incineration plant. Doubts related to these cases are 
usually connected with alleged health risks, fear of noise and landscape change, which may lead to a drop in the quality of life and a reduction in the value of real estate [31], [32]. Overcoming the effect can take place by education or by the invitation of individual stakeholders to cooperate - including participation in profits achieved from completed projects.

\section{CONCLUSION}

Highly developed countries have effective energy technologies that enable them to build an environmentally sustainable energy system. The main problems remain the problems of low social awareness and lack of responsibility for the natural environment.

Energy transformation requires that any changes in energy policy should be preceded by an improvement in public awareness. The basic thing is to overcome the barrier of knowledge. An excellent and widely cited example of how a society can be involved in the construction of energy systems is Denmark, where education and the inclusion of public participation in the energy policy have achieved an unprecedented success and built a competitive energy system.

\section{CONFLICT OF INTEREST}

The author declares no conflict of interest.

\section{AUTHOR CONTRIBUTIONS}

The article was entirely prepared by Grzegorz Maśloch.

\section{REFERENCES}

[1] F. E. Banks, Energy and Economic Theory, London: World Scientific, 2015, pp. 401-409.

[2] J. Chow, R. J. Kopp, and P. R. Portney, "Energy resources and global development," Science, vol. 302, p. 1528, 2003.

[3] J. Twidell and T. Weir, Renewable Energy Resources, New York: Taylor \& Francis, 2006, p. 3.

[4] Global Public Opinion on Nuclear Issues and the IAEA Final Report from 18 Countries, the International Atomic Energy Agency, Vienna, 2005, pp. 10-23.

[5] R. Fujita, "General remarks regional revitalization in Fukushima prefecture," Denki Hyoron, vol. 100, no. 11, pp. 7-12, 2015.

[6] P. Moriarty and D. Honnery, "What is the global potential for renewable energy?" Renewable and Sustainable Energy Reviews, vol. 16 , p. 245, 2012.

[7] M. S. Rana and F. S. AlHumaidan, "Statistical data on worldwide coal reserves, production, consumption, and future demand," in Coal Production and Processing Technology, M. R. Riazi, R. Gupta, ed. Boca Raton FL: Taylor \& Francis Group, 2016, p. 32.

[8] J. Luukkanen, J. Vehmas, and S. Mustonen, Finnish Energy Industries - Energy Scenarios and Visions for the Future, Turku: Finland Futures Research Centre, Turku School of Economics, 2009, pp. 8-39.

[9] C. C. Lee and C. P. Chang, "Energy consumption and GDP revisited: A panel analysis of developed and developing countries," Energy Economics, vol. 29, p. 1206-1223, 2007.

[10] J. M. Polimeni, K. Mayumi, M. Giampietro, and B. Alcott, The Myth of Resource Efficiency: The Jevons Paradox, New York: Earthscan, 2009.

[11] T. Żylicz, "The economics international environmental cooperation," Polish Studies in Economics, vol. 3, p. 126, 2015.

[12] D. I. Stern, "The rise and fall of the environmental Kuznets curve," World Development, vol. 32, p. 1419, 2004.
[13] E. Jankowska, "Środowiskowa krzywa Kuznetsa w dekarbonizacji europejskich gospodarek," Studia Ekonomiczne. Zeszyty Naukowe Uniwersytetu Ekonomicznego w Katowicach, no. 289, p. 55, 2016.

[14] N. Klein, To Zmienia Wszystko. Kapitalizm Kontra Klimat, Warsaw: Muza, 2016, p. 425.

[15] E. Jankowska, "Środowiskowa krzywa Kuznetsa w dekarbonizacji europejskich gospodarek," Studia Ekonomiczne. Zeszyty Naukowe Uniwersytetu Ekonomicznego w Katowicach, no. 289, p. 61, 2016.

[16] T. Żylicz, Ekonomia Środowiska i Zasobów Naturalnych, Warsaw: Polskie Wydawnictwo Ekonomiczne, 2004, p. 171-173.

[17] M. Bekkeheien, Ø. Håland, and R. Klovenings. (1999). Energy demand patterns towards 2050. Energy. The Next Fifty Years. OECD. [Online]. pp. 95-96. Available: www.oecd.org/futures/17738498.pdf

[18] K. W. Robert, T. M. Parris, and A. A. Leiserowitz, "What is sustainable development? Goals, indicators, values, and practice," Journal Environment: Science and Policy for Sustainable Development, vol. 47, issue 3, pp. 8-21, 2005.

[19] J. Goldemberg, "Renewable energy. Energy efficiency, and emissions trading," in Harnessing Renewable Energy in Electric Power Systems: Theory, Practice, Policy, B. Moselle, J. Padilla, and R. Schmalensee, ed. Washington DC: RFF Press, 2010, p. 100.

[20] M. S. Rana and F. S. AlHumaidan, "Statistical data on worldwide coal reserves, production, consumption, and future demand," in Coal Production and Processing Technology, M. R. Riazi and R. Gupta, ed. Boca Raton FL: Taylor \& Francis Group, 2016, p. 31.

[21] C. Mitchel, The Political Economy of Sustainable Energy, Basingstoke: Palgrave Macmillan, 2010, p. 9.

[22] T. Panek, Jakość Życia: Od Koncepcji do Pomiaru, Warsaw: SGH, 2016, pp. 29-34

[23] G. Seyfang, The New Economics of Sustainable Consumption. Seeds of Change, Ney York: Palgrave Macmillan, 2009, p. 49.

[24] J. Chow, R. J. Kopp, and P. R. Portney, "Energy resources and global development," Science, vol. 302, p. 1531, 2003.

[25] J. Rifkin, The Third Industrial Revolution: How Lateral Power Is Transforming Energy, The Economy, and the World, New York: Palgrave Macmillan, 2011, pp. 9-106.

[26] A. Dąbrowski, "Podstawowe rodzaje świadomości we współczesnej filozofii naturalistycznej," Diametros, no. 36, p. 27, 2013.

[27] K. Puchalski, Zdrowie w Świadomości Społecznej, Lodz: Krajowe Centrum Promocji Zdrowia w Miejscu Pracy, 1997, p. 46.

[28] J. Maciejewski, "Procesy społeczne a zmiany świadomości w kwestiach bezpieczeństwa," Acta Universitatis Wratislaviensis, no. 3096, Socjologia XLV, p. 8, 2009.

[29] Z. Łucki, "Wyzwania energetyczne Polski w świetle spójności społeczno-ekonomicznej," Nierówności Społeczne a Wrrost Gospodarczy, no. 18, p. 380, 2011.

[30] R. Wüstenhagen, M. Wolsink, and M. J. Bürer, "Social acceptance of renewable energy innovation: An introduction to the concept," Energy Policy, vol. 35, pp. 2683-2691, 2007.

[31] D. Horst, "NIMBY or not? Exploring the relevance of location and the politics of voiced opinions in renewable energy siting controversies," Energy Policy, vol. 35, pp. 2705-2714, 2007.

[32] S. Sims, P. Dent, and G. R. Oskrochi, "Modelling the impact of wind farms on house prices in the UK," International Journal of Strategic Property Management, no. 12, pp. 251-269, 2008.

Copyright (C) 2020 by the authors. This is an open access article distributed under the Creative Commons Attribution License which permits unrestricted use, distribution, and reproduction in any medium, provided the original work is properly cited (CC BY 4.0).

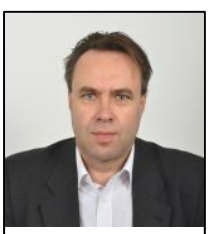

Grzegorz Maśloch is employed as an assistant professor at the Department of Local Government Economy and Financing at the Warsaw School of Economics. He is also working as the chairman of the scientific council in the Polish Economic Chamber of renewable energy sources and effective energy.

His research interests focus on issues related to local lopment, especially in terms of strategic planning of local and regional development, and also on issues concerning investment and financial plans and the preparation and implementation of investment projects, including those co-financed from EU funds. 